\title{
The Level of Teacher's Preparedness for Teaching and Assessing Children at a Hospital-Based School in Peninsular Malaysia
}

\author{
Sugendran Nagandran \\ Faculty of Educational Studies, Universiti Putra Malaysia \\ 43400 UPM Serdang, Selangor, Malaysia \\ Aminuddin Hassan (Corresponding author) \\ Faculty of Educational Studies, Universiti Putra Malaysia, \\ 43400 UPM Serdang, Selangor, Malaysia \\ Noraziela Abdul Majid \\ Faculty of Educational Studies, Universiti Putra Malaysia \\ 43400 UPM Serdang, Selangor, Malaysia
}

Norlizah Che Hassan

Faculty of Educational Studies, Universiti Putra Malaysia 43400 UPM Serdang, Selangor, Malaysia

Siti Suria Salim

Faculty of Educational Studies, Universiti Putra Malaysia 43400 UPM Serdang, Selangor, Malaysia

Tel: +60397698210 E-mail: ssuria@ upm.edu.my

Siti Salina Mustakim

Faculty of Educational Studies, Universiti Putra Malaysia 43400 UPM Serdang, Selangor, Malaysia 
Received: Oct. 8, $2021 \quad$ Accepted: Nov. 15, 2021 Online published: Nov. 25, 2021

doi:10.5296/ijhrs.v11i4S.19250

URL: https://doi.org/10.5296/ijhrs.v11i4S.19250

\begin{abstract}
The establishment of hospital-based school (HBS) in Malaysia is an excellent step forward in helping patients, who are unable to attend school, continue receiving their education. The Education Ministry of Malaysia, in collaboration with the Ministry of Health, initiated the idea of (HBS) in response to concerns over the fate of hospitalized children who were missing out on school. However, the effectiveness of the program depends largely on the willingness of teachers to go beyond the school infrastructure and facilities. This study was conducted to identify the level of self-sufficiency of HBS teachers when implementing teaching and learning (PdP) in various aspects such as controlling the concept of entertainment in PdP, motivation and positive attitude of teachers, as well as the state of their emotional and physical health. The study adopted a quantitative method using questionnaires as the key research instrument. Respondents of this study consisted of 95 HBS teachers in Peninsular Malaysia using sampling techniques. The findings of the study showed that the ability and creativity of a teacher to manage various aspects including entertaining, portraying motivational and positive attitude, and maintaining emotional as well as physical health affects the level of preparedness of teachers during PdP in HBS.
\end{abstract}

Keywords: teaching and learning, hospital-based school, education during illness

\title{
1. Introductions
}

School inside the Hospital (HBS) is a joint initiative between the Ministry of Education Malaysia (MOE), Ministry of Health (MOH), and the Nurul Yaqeen Foundation (YNY) to provide the opportunity for patients undergoing hospital treatment to continue receiving formal education. As outlined in the National Philosophy of Education, the primary focus of the education system is to produce individuals who are intellectually, spiritually, emotionally and physically balanced and harmonious (Majid, Hassan \& Che Hassan, 2020). In line with such aim, lifelong learning was introduced widely as demonstrated through the implementation of the HBS establishment. The YNY, a charity-based institution chaired by Tan Sri Dato' Haji Muhyiddin bin Mohd Yassin, was established to to improve the economic, education, leadership, sprituality and cultural achievements of Malaysian society at large, especially for the Bumiputera (Office of Corporate Strategy and Communications, 2016). Alongside that, the encouragement and support from parents who want their children to continue their education through lifelong awareness have catalysed the establishment of 15 HBSs throughout the entire country (Utusan Newspaper, 2012; Hassan \& Wan Jusoh, 2020).

This method is offered free of charge to further ensure that student dropouts could be overcomed while also receiving long-term treatment. The learning curricullum in HBS is structured and formalized by the MOE under the Education Act 1996. Teachers are able to teach in a conducive environment while also adopting a more flexible approach towards 
teaching and learning based on the "Fun Learning" instruction (Hospital School Guidebook, 2011). This exercise aims to ensure that student education is not compromised despite being warded in the hospital. This is in line with the Education for All (EFA) goal of the United Nations Education Scientific and Cultural Organization (UNESCO), , as well as upholds the responsibility of the MOE to ensure that educational services are accessible to all school-aged children and adolescents (Ministry of Education Malaysia, 2014).

The Malaysian Education Development Plan (PPPM) 2013-2025, launched on 6 September 2013, placed equal access to quality education as the First Movement. It, therefore, demonstrates that the MOE is very concerned and serious about the issue of education opportunities for children. In line with that, the MOE realizes the potential for HBS teachers to educate students in the hospital that will enable them to become intellectually, spiritually, emotionally and physically balanced persons through a safe, purposeful and educational learning environment (Fairul \& Siti A'isyah, 2017; Kamarudin, TzeJiun, Talib, Hassan, 2017). The teaching and learning sessions are integrated with the national curriculum, which consists of five cycles, namely; (i) heart-to-heart; (ii) PdP planning; (iii) PdP implementation; (iv) reflection and recovery; and (v) strengthening and enrichment (Ministry of Education Malaysia, 2012). Learning sessions with the use of appropriate teaching aids could motivate and stimulate students to continue learning (Hassan, Maharoff, Abiddin \& Ro'is, 2015) while also instill the courage to fight against the health problems their facing and eliminate boredom while in the hospital. Besides, they are not required to go through the school-level examinations. Nonetheless, if a student had already registered for school examinations such as the Primary School Achievement Test (UPSR), Form 3 Assessment (PT3) or Malaysian Certificate of Examination (SPM), they will still be given the opportunity to take the examination as well as prepare for it.

According to Zarinah (2016); Hassan \& Maharoff (2014), teachers act as catalysts in reforming a country's education system to produce a generation of high-minded, competitive and competent people in all aspects. This aspect is supported by former Deputy Education Minister Dr Maszlee Malik who, during his tenure, was successful in implementing various reforms to improve the national education system, especially in improving infrastructure of schools throughout the country (Sinar Harian, 2020). Therefore, teachers involved in the HBS program should be creative and intelligent in adopting appropriate approaches to suit the needs of these students that are made up of different learning capabilities and health conditions (Norhidani \& Norasmah, 2018; Saybani, Yusof, Soon \& Hassan, 2015). As such, the preparedness of teachers plays an important factor to the effectiveness of PdP implemented in HBS.

However, there have been studies which suggest that although HBS teachers are prepared to teach, the PdP approach implemented by some teachers have not been entertaining and flexible enough to be effective for HBS students (Normah \& Ruhaiza, 2014). This is partly due to the amount of time spent in handling daily and administrative tasks causing a lack of time in preparing for an entertainment-based approach in the PdP. Notwithstanding, some teachers take the initiative to come an hour early to prepare materials for the PdP that adopts the concept of entertainment. Implementing the learning process in the PdP process will help make the 
learning process more interactive and student-centred. For students participating in the HBS program, combining entertainment into the PdP does not only encourage their learning interests, it also promotes bereavement therapy, alleviates pain as well as exercises psychomotor and creative skills (Siti Salmiah, 2014; Hassan, Suhid, Abiddin, Ismail, \& Hussin, 2010). Although planning for the appropriate activities to suit the interest of students can be challenging, it should still be wisely managed while also striving for further improving the teaching methods to adopt the concept of entertainment.

Teaching a group of students with various type of health problems makes the preparation for PdP in HBS more challenging. As such, HBS teachers are usually concerned about their own physical health to implement PdP properly. According to (Wong and Cheng, 2012), as a responsible group of educators, they play an important role in educating students on the importance of healthy lifestyle practices. This is in line with (Cummings-Vickaryous \& LeDrew, 2011), which states that school teachers should be healthy as they act as 'active role models' for the students in HBS. Pupils pursuing treatment at the hospital are prone to emotional health problems while also have low concentration and ability capacity ( $\mathrm{Au}, 2014$; Sulaiman, Hassan, Sapian, Abdullah, 2009). This is caused by a variety of student health problems when they are in a hospital environment surrounded by other patients and thus creates discomfort in following PdP in the hospital. Therefore, HBS teachers should address this problem by adjusting and creating a more conducive environment than the normal hospital conditions when implementing PdP in HBS. Furthermore, this issue is closely related to the ability of teachers to conduct heart-to-heart sessions and student welfare (Hassan, \& Maharoff, 2014). However, the study found that teachers did not take into account aspects of emotional readiness, psychomotor as well as cognitive functioning when conducting a class in the ward or HBS provided by the Hospital.

\subsection{Problem Statement}

The Malaysian HBS Model was based on (The Children's Hospital at Westmead Royal North Shore Hospital and Sydney Children's Hospital, Randwick, Australia) tailored to the Malaysian context (School in Hospital Program Implementation Manual, 2014). The the HBS program is more focused on the entertainment aspect to meet the needs of children with disabilities while also meeting their needs as students. So teachers who design and implement PdP should take into account location, classroom environment, lesson titles, abilities, and interests. Based on the above scenario, drastic improvements should be made to ensure high-quality PdP implementation in HBS such as enhancing courses and training for teachers' self-centred learning strategies, self-information, self-efficacy and self-assessment in HBS (School Program Implementation Manual Hospital, 2014). This course or training enhances the motivational skills and ability of HBS teachers to deal with students of multiple levels of intelligence learning at the same time.

However, the research found that HBS teachers face difficulties in designing and preparing lesson plans when the attendance of students is at the discretion of the doctor, which also means that they may be removed from the ward at any time. Therefore, HBS teachers should be prepared to face and handle the challenges of implementing PdP to improve the quality of teaching in HBS. Suggestions and improvements towards addressing ineffective teacher 
readiness in PdP can be submitted for the actions of all involved in PdP management, especially in HBS. Therefore, this research should be done to identify the importance of teacher readiness to design effective PdP for students in HBS to be given the same quality of education provided in normal schools, in turn, ensuring that the student will not lose the opportunity to gain knowledge.

\subsection{Objectives}

In summary, this study aims to identify the level of teacher readiness in preparing PdP for students in HBS. In line with that, the specific objectives of this research are as follows;

i. To identify the level of readiness of teachers in planning and implementing PdP for hospitalized students to achieve their learning objectives.

ii. To identify the experience of the HBS teacher applying PdP in terms of teacher motivation and positive attitude.

\subsection{Concept of Hospital-based School (HBS)}

HBS is a specialized, structured hospital learning centre focused on the readiness and capacity of students with disabilities (HBS program implementation manual, 2014). The objective of this educational facility is to encourage students with health problems to engage in an entertainment-oriented learning approach as a healing process while receiving hospital treatment with teachers as facilitators for implementing PdP in a conducive manner (HBS program implementation manual, 2014). The conduct of conducive learning promotes moral and motivated support for the cure of normal and psychosocial illness among students. It is also an educational concept that helps to improve the knowledge and skills of patients, especially school-aged patients, towards a healthier lifestyle so as to avoid other complications (Ministry of Health Malaysia Official Portal, 2012).

HBS adopts the 'Fun Learning' approach which emphasizes having fun while learning to create a conducive learning atmosphere. A calm, engaging and colourful learning environment can be a natural therapy for students and children in hospitals (Utusan Malaysia, 2012). The concept of HBS was already established in several developed countries such as the United States, the United Kingdom, Canada and Australia in line with UNESCO's recommendation for 'education for all'. HBS in Malaysia has started to gain traction among parents with children in under long-term hospital care. The government has plans to open HBS in three other hospitals nationwide in future, including in Sabah and Sarawak which received positive reactions from the public (HBS program implementation manual, 2014).

\subsection{Level of Readiness Teacher in HBS}

The role of teachers as a key pillar in the empowerment and development of education in this country is undeniable (Mohd Fadzly, 2011). The role of the teacher is highly regarded and recognized not only as a communicator of knowledge or personality development but also as the generation of highly intelligent people. Teachers are important people and intermediaries in the field of education to pass on knowledge to students and to apply it and realize it in an increasingly challenging environment of the world. According to Rafferty, Jimmieson \& 
Armenakis (2013), readiness is an issue for any change. Readiness for change is crucial in determining the success of an organization's innovation (Davis, 1989; Teo, 2010; Anghelachea \& Bentea, 2012). Similarly, HBS teachers should be prepared to adapt to challenges in implementing the PdP process for students with health problems.

Teachers play an important and responsible role in the development of the nation towards realizing the aspiration of the National Philosophy of Education. It is therefore crucial for teachers to focus on effective preparation and planning of PdP as they will drive the future excellence of the nation (Zamri, 2014; Noriati, Boon \& Wong, 2010). As such, issues of teacher readiness are important as the literature reveals that teacher influence is crucial in determining the outcome of a change in a nation (Hall \& Hord, 2011). According to Erwin \& Garman (2010), individual reluctance has been identified as the cause of failure to implement change. Teachers are often found to be problematic in terms of readiness, such as the findings of Toprak \& Summak (2014). In this regard, teachers need sufficient time and energy in preparing PdP materials and lesson plans.

This readiness study uses a conceptual framework modified from Dick and Reiser's (1996) systematic learning model. According to this framework, the process of identifying readiness of teachers occurs after reviewing the goals, content standards and emphasis they aim to achieve.

\subsection{The Motivating aspects and Positive Attitude of Teachers}

The teaching profession is a very challenging profession, given the various tasks and responsibilities they have to shoulder. As such, teachers at HBS should be more motivated to perform their tasks than the regular daily schools, given their extra burden of handling students with different types of health problems. According to Sahandri (1998), the level of motivation refers to action, direction, intensity and persistence of behaviour. In assessing a teacher's motivation, the two main aspects considered include the motivation for the presentation and the character of a teacher. The guide for assessing the motivation of teachers is based on the Malaysian Education Quality Standards (SKPM) provided by the MOE, which was released in 2003.

Attitude is defined as a mental process of the mind, feeling or response to a particular object, aspect or situation (Ismail, 2012) that induces an individual to show a tendency toward something or thing or event (Azmi \& Ahmad, 2008). From this definition, attitude can be interpreted as a reaction that reflects feelings of dislike or indulgence through behavioural changes such as prejudicial behaviour, prosocial discrimination and so on (Village, 2009). Attitude plays an important role in implementing appraisals (Yan \& Cheng, 2015). In this research, the motivational level is the driving force involved in the process of arousing, maintaining and controlling one's self-interest (Bernard, HW 1965 in Kamaruddin Hussin, 1993). The level of teacher motivation can determine the effectiveness of teacher readiness in implementing PdP in the classroom. To this end, students are influenced by the teaching of teachers on a strong and persistent impulse to pursue PdP in HBS. One of how HBS teachers use effective methods is intensive techniques and motives. Extensive methods in PdP in extrinsic form of praise, star and positive guidance to students. In contrast, the motive is the natural impulse of the teacher's tendency to achieve the lesson objectives taught in HBS 
despite taking a long time for students with disabilities.

Teachers who practise good manners will be loved by students (Atan, 1992). Students will be more likely to approach teachers with interesting personalities and behaviours such as friendly, caring and attentive about the things they do. Besides, teachers who regularly attend classes, calm in delivering lessons, responsible and confident are more likely to be welcomed by HBS students. HBS students will be able to participate in the teaching process more easily and quickly if the teacher delivering the lesson is more concerned with the needs and development of the PdP. Such concerns include concern towards the welfare of the students. In this regard, the level of teacher readiness in terms of teacher motivation and a positive attitude can help the PdP to adapt to today's student development, teachers can easily understand the student situation and enhance the effectiveness of the teaching and professionalism of the teacher. In this regard, aspects of behaviour such as positive attitude that is highlighted by teachers and pupils as a result of effective PdP implementation can be interesting and active in learning, teachers remain adhering to assessment ethics, highly motivated and striving to improve knowledge.

HBS teachers should take the initiative to come to HBS early to make appropriate preparations for the PdP. The positive attitude of the teacher exemplifies a positive role model for students attending HBS as well as encouraging continuous PdP. However, the number of pupils will change after having completed treatment at the hospital. So HBS teachers should always be proactive in preparing for early childhood education according to the circumstances and the number of students attending HBS to continue their lessons. The display of positive attitudes and level of teacher motivation play an important role in implementing PdP outside of the regular school environment. This attitude encourages an attitude of life-learning among the students that motivates them to continue learning even after school.

\section{Methodology}

This study adopts quantitative methods leveraging on a questionnaire as the main research tool. The preferred sampling for this research was based on the selection of 95 HBS teachers across various HBS throughout Peninsular Malaysia. The main instrument used to answer the research question is the questionnaire form. The questionnaire items were adapted and modified from the Special Education Division's self-assessment verification instrument, KPM (2016), and the evaluation instrument of the implementation of the HBS Special Education Division, KPM (2015) program. A letter of approval to conduct the study at HBS was requested from the Education Policy Research and Development Division (EPRD), KPM to provide questionnaires to HBS teachers across Malaysia. The results of the study were divided into two sections, namely; (i) descriptive; and (ii) inference analysis. Researchers will present descriptive data to see how frequency and percentage of sex, age, duration of service in HBS and the subjects studied affect the frequency of hypotheses constructed for this study whether they are accepted or rejected. At the same time, inference analysis is used to link the teacher readiness level with the implementation of $\mathrm{PdP}$ to achieve the learning objectives in HBS. 


\section{Ml Macrothink}

International Journal of Human Resource Studies

ISSN 2162-3058

2021, Vol. 11, No. 4S

The first part of the questionnaire (Section A) was the demographic background of the participants which includes:
I. Gender;
II. Age;
III. Position;
IV. Academic qualifications;
V. Teaching experience in HBS;
VI. Services in HBS;
VII. Subjects currently being taught in HBS.

The second part of the questionnaire (Section B) was Inference Analysis which related to:

\section{Research Objectives 1: Identify the level of teacher readiness in planning and implementing PdP for hospitalized students to achieve the lesson objectives.}

This section looks at the relationship between a teacher's preparedness level in the aspect of entertainment-education that is a priority for teachers in achieving educational objectives, especially in HBS. Therefore, Pearson correlation coefficients were conducted to answer the above study because the data were normal. Referring to Pallant (2005), quoting from Cohen (1998) a small correlation is reflected by values of 0.1 to 0.29 , while values of 0.30 to 0.49 reflect moderate to high correlations and values of 0.50 to 1.0 indicate large correlations.

Table 1. Level of teacher readiness in planning and implementing PPP for hospitalized students to achieve the learning objectives

\begin{tabular}{|c|c|c|c|}
\hline \multicolumn{4}{|c|}{ Correlations } \\
\hline & & $\begin{array}{l}\text { The level of } \\
\text { readiness of } \\
\text { teachers in } \\
\text { performing } \\
\text { entertainment in } \\
\text { HBS }\end{array}$ & $\begin{array}{l}\text { The level of } \\
\text { readiness of teachers } \\
\text { in implementing } \\
\text { PDP in HBS }\end{array}$ \\
\hline \multirow[b]{3}{*}{$\begin{array}{l}\text { The level } \\
\text { readiness } \\
\text { teachers } \\
\text { performing } \\
\text { entertainment } \\
\text { HBS }\end{array}$} & Pearson Correlation & 1 & .072 \\
\hline & Sig. (2-tailed) & & .489 \\
\hline & $\mathrm{N}$ & 95 & 95 \\
\hline \multirow{3}{*}{$\begin{array}{lr}\text { The level } & \text { of } \\
\text { readiness } & \text { of } \\
\text { teachers } & \text { in } \\
\text { implementing } & \text { PDP } \\
\text { in HBS } & \end{array}$} & Pearson Correlation & .072 & 1 \\
\hline & Sig. (2-tailed) & .489 & \\
\hline & $\mathrm{N}$ & 95 & 95 \\
\hline
\end{tabular}

Based on Table 1, the high correlation coefficient Pearson ( $r$ ) node shows a positive correlation between teacher readiness in the implementation of PdP, which is $r=.072$ at .489 . The coefficient of correlation of .072 indicates small correlation. The increase in the nodes will lead to an increase in the level of teacher readiness in implementing PdP in HBS having a positive 
network in the provision of entertainment aspects aimed at achieving the learning objectives in HBS. Teacher readiness level had a high $r=.072$ in the implementation of PdP in HBS.

Table 2. Statistical Descriptive Statistics Table

\begin{tabular}{|c|c|c|c|}
\hline \multicolumn{4}{|c|}{ Descriptive Statistics } \\
\hline & Mean & $\begin{array}{c}\text { Std. } \\
\text { Deviation }\end{array}$ & $\mathrm{N}$ \\
\hline $\begin{array}{l}\text { Providing PDP-based planning for } \\
\text { entertainment is easier to implement in } \\
\text { HBS. }\end{array}$ & 3.93 & .672 & 95 \\
\hline $\begin{array}{l}\text { It took me a long time to provide the } \\
\text { entertainment element in PDP }\end{array}$ & 2.22 & .840 & 95 \\
\hline $\begin{array}{l}\text { I can easily provide fun and relaxing } \\
\text { learning elements in HBS }\end{array}$ & 3.92 & .613 & 95 \\
\hline $\begin{array}{l}\text { The provision of an entertainment element } \\
\text { allows me to teach in fun and make } \\
\text { learning sessions more productive }\end{array}$ & 4.37 & .485 & 95 \\
\hline $\begin{array}{l}\text { The concept of amusement education can } \\
\text { attract students in HBS }\end{array}$ & 4.46 & .501 & 95 \\
\hline $\begin{array}{l}\text { I am trying to find information and } \\
\text { resources that are conceptually } \\
\text { entertaining in the preparation of PDP } \\
\text { planning }\end{array}$ & 4.43 & .539 & 95 \\
\hline $\begin{array}{l}\text { The students did not well receive the } \\
\text { provision of entertainment-education by } \\
\text { me at HBS }\end{array}$ & 1.75 & .564 & 95 \\
\hline $\begin{array}{l}\text { The provision of a "Gamification" } \\
\text { entertainment-education has encouraged } \\
\text { me to design an effective PDP in HBS }\end{array}$ & 4.11 & .660 & 95 \\
\hline $\begin{array}{l}\text { I always plan more carefully in providing } \\
\text { entertainment for every learning session at } \\
\text { HBS }\end{array}$ & 4.17 & .647 & 95 \\
\hline $\begin{array}{l}\text { I have always taken my initiative to } \\
\text { provide entertainment learning that } \\
\text { involves acting, elegance and aesthetic } \\
\text { elements }\end{array}$ & 4.09 & .701 & 95 \\
\hline $\begin{array}{l}\text { I did not make bilateral communications } \\
\text { during the implementation of the } \\
\text { amusement approach in PDP }\end{array}$ & 1.76 & .725 & 95 \\
\hline $\begin{array}{l}\text { I do not provide any more assignments or } \\
\text { training to students in HBS }\end{array}$ & 3.61 & 1,085 & 95 \\
\hline
\end{tabular}




\section{$\triangle$ Macrothink}

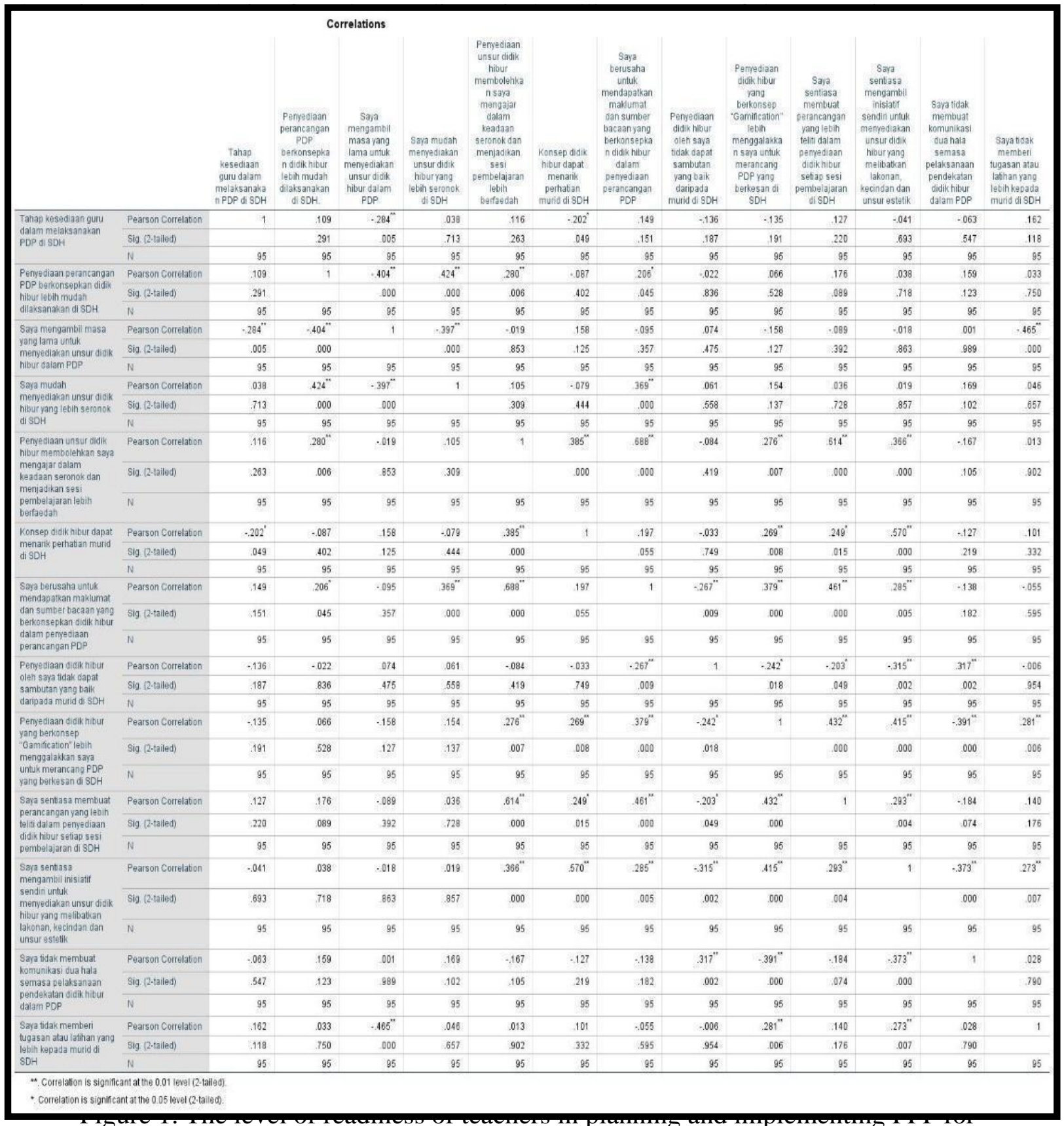

hospitalized students to achieve their learning objectives

In Figure 1, the level of teacher readiness in implementing PdP shows higher coefficients in the form of simpler conceptualization of conceptual learning which is $r=0.11$ at a .01 level. The correlation is small for the design of the entertainment concept. Whereas teacher readiness levels show a negative correlation coefficient since teachers consume a large amount of time to prepare an entertainment element before PdP, which is $r=-.28$ where teachers come to HBS two hours early to provide PdP for students with health problems. On the contrary, the coefficient value of teacher readiness that are easy to provide entertainment element and made the PdP session more enjoyable had a high positive correlation of $r=.26$ at a .11 level. The level of readiness of teachers in the implementation of the PdP-based entertainment instruction also showed high coefficient in the form of information retrieval in 


\section{Ml Macrothink}

the concept of reading concept that was $r=.15$ at a significant level of .149 . Also, the level of teacher readiness in with careful planning of the element of entertainment added with the concept of Gamification showed high coefficients of $r=.22$ and $r=.19$ respectively. These values show a significant positive correlation in the implementation of $\mathrm{PdP}$ to achieve the learning objectives. While the level of teacher readiness in the form of entertainment element did not respond well, and without a two-way communication showing negative mean coefficients of $r=-.14$ and $r=-.06$, respectively.

\section{Research objective 2: Identify the experience of the HBS teacher applying PdP in terms of teacher motivation and positive attitude}

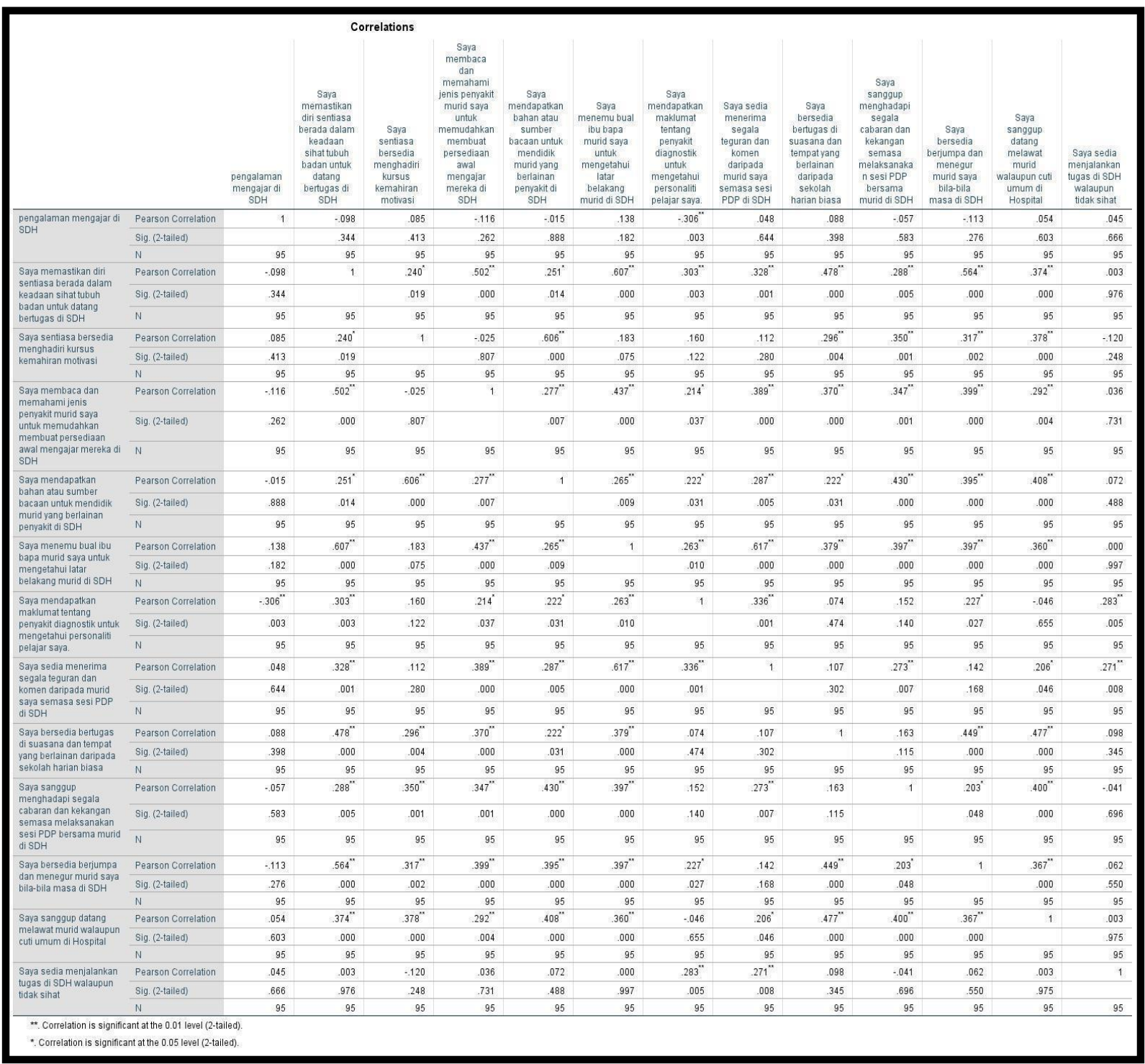

Figure 2. Correlation Table of Teacher Experience Level of Teacher Readiness in aspects of motivating students

Table 3. Table of Analysis and Frequency of Teacher Experience Level Self-preparedness in terms of motivation and positive attitude 


\begin{tabular}{|c|c|c|c|}
\hline \multicolumn{2}{|c|}{ Descriptive Statistics } & $\begin{array}{c}\text { Std. } \\
\text { Deviation }\end{array}$ & N \\
\hline $\begin{array}{c}\text { Mean } \\
\text { to HBS }\end{array}$ & 4.53 & .523 & 95 \\
\hline $\begin{array}{c}\text { I maintain that I am in good health to come } \\
\text { skills courses }\end{array}$ & 4.54 & .522 & 95 \\
\hline $\begin{array}{c}\text { I'm always ready to attend motivational } \\
\text { students' illnesses to facilitate their initial } \\
\text { preparation for teaching at HBS }\end{array}$ & 4.33 & .515 & 95 \\
\hline $\begin{array}{c}\text { I find reading materials or resources to } \\
\text { educate students with different ailments in } \\
\text { HBS }\end{array}$ & 4.24 & .560 & 95 \\
\hline $\begin{array}{c}\text { I interviewed my parents' parents to find } \\
\text { out about their background in HBS }\end{array}$ & 4.46 & .598 & 95 \\
\hline $\begin{array}{c}\text { I get information about diagnostics to find } \\
\text { out my students' personalities. }\end{array}$ & 3.99 & .707 & 95 \\
\hline $\begin{array}{c}\text { I am ready to receive all the comments and } \\
\text { comments from my students during the } \\
\text { PDP session at HBS }\end{array}$ & 4.35 & .597 & 95 \\
\hline $\begin{array}{c}\text { I'm ready to work in a different setting and } \\
\text { place than a regular school day }\end{array}$ & 4.48 & .502 & 95 \\
\hline $\begin{array}{c}\text { I am willing to meet the challenges and } \\
\text { obstacles of conducting PDP sessions with } \\
\text { students at HBS }\end{array}$ & 4.39 & .532 & 95 \\
\hline $\begin{array}{c}\text { I am ready to meet and admonish my } \\
\text { students anytime in HBS }\end{array}$ & 4.38 & 1,031 & \\
\hline $\begin{array}{c}\text { I was willing to come to visit a student on } \\
\text { a public holiday at the Hospital }\end{array}$ & 3.82 & & 95 \\
\hline
\end{tabular}

The results in Figure 2, correlate with teacher readiness level with the teacher's experience in motivating and the positive attitude of the teacher to the value of the coefficient in the form of always being in good health condition when working at HBS which is $r=-.09$ at a significant level of .34. This reflects a moderate negative correlation given that long-serving teachers are burdened with administrative work, so they do not have enough time to ensure the health of each class they attend. Teacher experience in the preparation of motivation from the next aspect of attending motivational skills courses as well as reading and understanding the types of student illness before implementing PdP showed a coefficient of $r=.08$ at a significant level. .41 and $r=-.11$ at a significant level of .26. The teacher correlation value of the motivation course is positively modest. This shows that young and experienced teachers are encouraged to attend motivational courses to gain positive knowledge and skills. 
The value of the teacher experience coefficient in motivating and positive attitude in the form of student feedback and comments during the implementation of the PdP showed an $r=.04$ at a significant .01 level. High levels of motivation and positive attitude towards teachers indicate a value of the coefficient in the form of willingness to visit pupils despite leave $r$ $=.05$ at a significant level of .6. This is because all teachers are entitled to a public holiday, and they are entitled to a special leave of absence as provided by the MOE.

The conclusion here is that nodes have a high coefficient of correlation inexperienced teachers who teach in HBS play an important role in motivating and positively influencing the willingness of teachers to teach students with health problems. Young teachers serving at HBS are ready to take on the challenge and learn from highly experienced teachers.

\section{Discussion}

Study discussion: The level of teacher readiness in planning and implementing PdP to achieve lesson objectives

The findings of the above question were answered through the correlation test where this study was related to the level of teacher readiness in implementing PdP using the entertainment element to achieve the learning objectives in HBS. This is evident in the study data of chapter 4 teacher readiness level of correlation in $r=.072$ using the element of learning in PdP was high and received good response from HBS students.

Besides, some teachers took the initiative to come an hour early to prepare the PdP based on the concept of entertainment. This method is supported by Khairul (2014), which states that the level of teacher readiness, including the preparation of a carefully planned daily teaching plan is the key to success in any teaching. Adopting a fun learning approach in the PdP process will help the learning process become more interactive and student-centred. For students participating in the HBS program, the entertainment approach is not only interesting for them to learn, it can also be a form of therapy in reducing boredom, easing pain as well as training psychomotor skills and creativity (Siti Salmiah 2014). Therefore, teachers should take the initiative to provide an entertainment element in the implementation of PdP for students in HBS to create a more conducive learning condition for the students.

The main purpose of teaching is to convey the purpose of the lesson being planned as well as new skills based on the syllabus set. The achievement of a teaching objective depends entirely on the method used by the teacher. Accordingly, in the PdP process verbal communication should not be the sole medium to be used during lessons. Other relevant tools and materials for teaching should also be used in order for the PdP to be more effective and reach its intended message (in Juriah Long \& Noor Ein, 1990). So HBS teachers use the element of learning in PdP to maintain student focus while creating the atmosphere and facilitating students' understanding of the topics being taught to achieve the lesson objectives planned by the teacher.

Study discussion: The level of readiness of teachers concerning the HBS teacher experience implement PdP in terms of teacher motivation and positive attitude 
The analysis was performed using the Pearson correlation test, and the results are presented in Table 4.3. This test was conducted because the frequency in HBS teacher demographics indicated that the majority of teachers had more teaching experience. Thus the hypothesis was developed, Ho1: there was no significant relationship between the experience of a teacher and PdP implementation. The results shown in Table 4.3 indicate that there was a significant relationship between teacher teaching experience and PdP implementation with a value of $\mathrm{r}=.043, \mathrm{p}<0.05$. However, the relationship rate is only modest. This result showed that the teaching experience of HBS teachers is modestly related to the implementation of PdP in HBS. In conclusion, Ho1 was rejected. Experienced teachers who teach in HBS play an important role in motivating readiness and positive attitude in the teacher's willingness to teach students with disabilities. This is because new teachers are ready to serve in HBS and face the challenge of positively learning from old-school teachers. This method, supported by Mohammad Haziq (2015), states that new teachers need to raise the level of competence of their long-serving teachers to help them learn the right techniques for a community. In this regard, teachers who teach at HBS have a strong commitment to their teaching. They have a neat and consistent teaching spirit in their teaching.

According to the findings of the study the level of readiness of teachers concerning teaching experience of age is not the main factor teacher readiness in the implementation of PdP but the willingness of a teacher based on the motivation and positive attitude of the teacher to adapt to the environment and to implement the PdP effectively and achieve the teaching objectives. Older teachers at HBS have more experience in teaching and teaching techniques than new teachers. However, new teachers tend to have different approaches to the implementation of PdP that attracts the attention of HBS students compared to long-serving teachers. This is in line with the educational article published by Natasha (2014), which states that the teaching approaches of a teacher influence student acceptance. In this regard, the government-run New Teacher Development Program in efforts to monitor new teachers is monitored by mentors appointed by administrators and experienced teaching for over five years (Ministry of Education Malaysia, 2014).

\subsection{Implication}

By always thinking ahead, teachers can anticipate the response of students and plan the lesson accordingly. In this regard, the level of readiness of HBS teachers in the effective implementation of PdP can lead to conducive learning sessions with hospitalized students. The planning and preparation of an entertainment-based PdP will catch the attention of students, in turn increasing their motivation to learn. The physical and emotional health of teachers enables interaction and integration in HBS with students. Therefore, increasing the confidence of students towards the readiness of the teacher during PdP sessions in HBS. The findings of this research is expected to provide better awareness regarding teacher preparedness and guide teachers to improve the delivery of lessons in HBS, in particular, and improve quality of education of the country, in general. Based on these readings, a theoretical concept was developed to guide this study. This conceptual framework is linked to the level of teacher readiness in the following aspects of implementing PdP to achieve the learning objectives in HBS. Therefore, the level of teacher readiness, including the preparation of a 
carefully planned daily teaching plan is the key to success in teaching (Khairul, 2014).

\section{Conclusion}

Based on the results discussed, it was found that the relationship between the level of teacher readiness in implementing PdP in various HBSs with the level of teaching experience was not statistically significant. The experience of a teacher affects the level of readiness in the aspects mentioned in the question that most teachers respond positively to the implementation of PdP in HBS. Social aspects with students have a positive impact on student engagement in $\mathrm{PdP}$ because they experience an engaging learning approach that captures their attention.

\section{References}

Abdul, R. J., \& Hasmah, I. (2013). Implementation of Fun Learning in Teaching and Learning The Malay Language. Journal of Education English, 3(2), 49-63.

Aida, M. A. (2014). Improving professionalism of SDH teachers. Proceedings of the 2nd Seminars in Hospitals. Putrajaya: Teacher Education Division, Ministry of Education, Malaysia. 33-39

Akhiar, P., Shamsina, S., \& Muhammad, K. J. (2012). The basics of teacher leadership and professional development. Kuala Lumpur: Freemind Horizons Sdn. Bhd

Asri, C. (2007). Teaching and learning assessment practices in Johor Darul Takzim state best schools (PhD's thesis). University of Technology Malaysia, Malaysia.

Daniatul, F. (2014). Impact of education, training and teaching experience on the professionalism of elementary school teachers in the district of B Construction IV district (E-Thesis Scholar). University of Semarang State, Indonesia.

Educational Policy Planning and Research Division. (2006). Educational development master plan. Putrajaya: Curriculum Development Division, Ministry of Education Malaysia.

Fatima, A. (2009). Implementation assessment of special rehabilitation programs (Doctor of Philosophy Thesis). Faculty of Education, national university of Malaysia.

Fullan, M. G., \& Stiegelbauer, S. (1991). The new meaning of educational change. (2nd. ed). London: Cassel Educational Limited.

Hassan, A., \& Maharoff, M. (2014). The understanding of curriculum philosophy among trainee teachers in regards to soft skills embedment. International Education Studies, 7(12), 84-94. https://doi.org/10.5539/ies.v7n12p84

Hassan, A., \& Wan Jusoh, W. Y. (2020). The relationship between orientations, ethnocentrism and parental roles in second language acquisition among form four students of fully residential schools in Terengganu. Universal Journal of Educational Research, 8(3), 9-16. https://doi.org/10.13189/ujer.2020.081602

Hassan, A., Asimiran, S., Abd Rahman, F., \& Kamarudin, N. (2008). Analyzing the application of National Philosophy of Education (NPE) throughout learning process in Higher 
Education Institutions (HEI): The students' perspectives. European Journal of Social Sciences, $7(2), 148-157$.

Hassan, A., Maharoff, M., Abiddin, N. Z., \& Ro'is, I. (2015). Teacher trainers' and trainee teachers' understanding towards the curriculum philosophy regarding soft skills embedment in the Malaysian Institute of teacher education. Policy Futures in Education, 14(2), 164-175. https://doi.org/10.1177/1478210315597857

Hassan, A., Mohamad, L. Z., Ismail, H., \& Yusoff, S. (2009). The approach of educational philosophy in overcoming social problem. European Journal of Scientific Research, 27(3), 463-471.

Hassan, A., Rashid, A.M., Ismail, I.A., Jalil, H.A., \& Rahman, F.A. (2008). The appreciation of Malaysian philosophy of education among academics and how it relates to their productivity. International Journal of Interdisciplinary Social Sciences, 3(5), 217-230. https://doi.org/10.18848/1833-1882/CGP/v03i05/52608

Hassan, A., Suhid, A., Abiddin, N.Z., Ismail, H., \& Hussin, H. (2010). The role of Islamic philosophy of education in aspiring holistic learning. Procedia - Social and Behavioral Sciences, 5, 2113-2118. https://doi.org/10.1016/j.sbspro.2010.07.423

Hassan, A., Tymms, P., \& Ismail, H. (2008). Academic productivity as perceived by Malaysian academics. Journal of Higher Education Policy and Management, 30(3), 283-296. https://doi.org/10.1080/13600800802155184

Isaac, B. (2009). Effectiveness of teaching and learning and its relation to the academic performance of Tun Hussein Onn university students. Short Term Grants Report. Tun Hussien Onn University, Johor.

Ismail, H., \& Hassan, A. (2009). Holistic education in Malaysia. European Journal of Social Sciences, 9(2), 231-236.

Kamarudin, N., TzeJiun, L., Talib, O., \& Hassan, A. (2017). Enhancing higher order thinking skills via inquiry-based laboratory practices among science students . Man in India, 97(17), 185-194.

Majid, N.A., Hassan, A., \& Che Hassan, N. (2020). Multi-ethnic students in Malaysia higher institutions: Relationship between racial integration and democratic outcomes. International Journal of Psychosocial Rehabilitation, 24(6), 2300-2314.

Malaysia Education Ministry. (2009). Malaysian teacher standards. Putrajaya: Teacher Education Division.

Malaysia Education Ministry. (2012). National curriculum implementation guide in Hospital schools. Putrajaya: Teacher Education Division.

Malaysia Education Ministry. (2013). Malaysian education development plan 2013-2025. Putrajaya: Curriculum Development Division.

Malaysia Education Ministry. (2013). Parental satisfaction survey of special education 
services. Putrajaya: Special Education Division.

Malaysia Education Ministry. (2014). Hospital school program implementation manual. Putrajaya: Teacher Education Division.

Malaysia Education Ministry. (2015). Implementation assessment of in-hospital school program. Putrajaya: Special Education Division.

Malaysia Education Ministry. (2015). Shift bulletin. Putrajaya: Educational Implementation and Performance Unit.

Malaysia Education Ministry. (2016). Verification of self-assessment. Putrajaya: Special Education Division.

Ministry of Education Malaysia. (2010). Educational development master plan (2006-2010). Launch of PIPP 2006. Published by the Ministry of Education Malaysia (MOE).

Norhaiza, T. (2015). The relationship of teacher personality to student science process skills. (master of research project report). Tun Hussein Onn University.

Norhidani, B., \& Norasmah, O. (2018). Implementation of Teaching and Learning in Hospital School Programs. Malaysian Journal of Education

Norliah, E. (2014). Assessment of KPM preschool education transformation program in national schools (Doctor of Philosophy Thesis). Faculty of Education, National University of Malaysia.

Normah, I., \& Isa. (2014). Challenges in teaching and learning quality in hospital schools. Proceedings of the 2nd Seminar in Hospital Secondary Times. Ministry of Education Malaysia: Teacher Education Division, 19- 32.

Pilgrims \& Quality Assurance. (2015). Corrective action and improvement of schools based on inspection findings. Seremban, April 1-2.

Saidy, E. P., Hassan, A., Abd. Rahman, F., Ab. Jalil, H., Ismail, I. A., \& Krauss, S. E. (2009). Influence of emotional and spiritual intelligence from the national education philosophy towards language skills among secondary school students. European Journal of Social Sciences, 9(1), 61-71.

Saybani, H. R., Yusof, A., Soon, C., \& Hassan, A. (2015). Transformational leadership and sport commitment: A study of Iranian high schools' football teams. Pertanika Journal of Social Sciences and Humanities, 23(4), 781-792.

Siti Salmiah, M. S. (2014). Teaching arts-oriented arts education at SDH. Proceedings of the Secondary In-Hospital School Seminar. Putrajaya: Teacher Education Division, Ministry of Education Malaysia, 114-128

Sulaiman, T., Hassan, A., Sapian, V. M., \& Abdullah, S. K. (2009). The level of stress among students in urban and rural secondary schools in Malaysia. European Journal of Social Sciences, 10(2), 179-184. 


\section{Copyright Disclaimer}

Copyright for this article is retained by the author(s), with first publication rights granted to the journal.

This is an open-access article distributed under the terms and conditions of the Creative Commons Attribution license (http://creativecommons.org/licenses/by/4.0/). 